\title{
Effect of environmental filters on Chironomidae (Insecta: Diptera) assemblages of neotropical watersheds
}

\author{
Wilma Izabelly Ananias Gomes ${ }^{1, *}$, Daniele Jovem-Azevêdo², Evaldo de Lira Azevêdo ${ }^{3}$, \\ Maria João Feio ${ }^{4}$, Franco Teixeira de Mello ${ }^{5}$ and Joseline Molozzi ${ }^{6}$ \\ ${ }^{1}$ Programa de Pós-Graduação em Ciência e Tecnologia Ambiental, Universidade Estadual da Paraíba, Campina \\ Grande, Paraíba, Brazil. \\ 2 Programa de Pós-Graduação em Ecologia, Conservação e Manejo da Vida Silvestre, Universidade Federal de \\ Minas Gerais, Belo Horizonte, Minas Gerais, Brazil. \\ 3 Programa de Pós-Graduação em Etnobiologia e Conservação da Natureza, Universidade Federal Rural de \\ Pernambuco, Recife, Pernambuco, Brazil. \\ ${ }^{4}$ University of Coimbra, Marine and Environmental Sciences Center, Department of Life Sciences, Calçada \\ Martim de Freitas, 3000-456 Coimbra, Portugal. \\ ${ }^{5}$ Departamento de Ecología y Gestión Ambiental, Centro Universitario Regional del Este, Universidad de la \\ República, Maldonado, Uruguay. \\ 6 Departamento de Biologia/Programa de Pós-Graduação em Ciência e Tecnologia Ambiental/ Programa de \\ Pós-Graduação em Ecologia e Conservação, Universidade Estadual da Paraíba, Campina Grande, Paraíba, \\ Brazil. \\ * Corresponding author: wilmaizabelly@hotmail.com
}

Received: 06/01/19 Accepted: 06/11/19

\begin{abstract}
Effect of environmental filters on Chironomidae (Insecta: Diptera) assemblages of neotropical watersheds

Environmental filters act at different spatial scales, selecting species with characteristics that allow them to successfully establish and survive under local environmental conditions. We sought to evaluate how environmental filters (physical/chemi$\mathrm{cal}$, habitat composition, and landscape) and different levels of anthropogenic disturbances affect the abundance of Chironomidae in neotropical semiarid watersheds. Chironomidae larvae were sampled in six reservoirs (112 sites) in the Piranhas-Assu and Paraíba watersheds (NE Brazil) during the dry season. The distribution of Chironomidae larvae was best explained in Least Disturbed sites, with $82.1 \%$ of the total explained variance in the Piranhas-Assu watershed and $64.2 \%$ in the Paraíba watershed. The interactions of filters (physical/chemical, habitat composition, and landscape) best explained the abundance distributions of Chironomidae larvae in the watersheds and sites subjected to different levels of anthropogenic disturbances. The physical/chemical conditions of the water as well as habitat composition depend on landscape characteristics, because anthropogenic activities in watersheds increase nutrient concentrations in the water, promoting the increase of the trophic state of the environment as well as habitat homogenization. This study showed that, independent of the anthropogenic disturbance level, interactions of environmental factors act as strong environmental filters on the distributions of local communities, such as Chironomidae assemblages.
\end{abstract}

Key words: environmental degradation, benthic macroinvertebrates, species selection, reservoirs, semi-arid

\section{RESUMO}

Efeitos dos filtros ambientais sobre as assembleias de Chironomidae (Insecta: Diptera) em bacias hidrográficas neotropical

Os filtros ambientais atuam em diferentes escalas espaciais selecionando espécies com características adequadas capazes de sobreviver e se establecer sob condições ambientais especificas. Procuramos avaliar como os filtros ambientais (fisico/quimico, composição do habitat e paisagem) e os diferentes niveis de distúrbios antropogênicos afetam a abundância de Chironomi- 
dae em bacias hidrográficas no semiárido neotropical. As larvas de Chironomidae foram amostradas em seis reservatórios (112 locais) nas bacias hidrográficas do rio Piranhas-Assu e do rio Paraiba (NE Brasil) durante a estação seca. A distribuição das larvas de Chironomidae foi melhor explicada nos locais menos perturbados, com $82.1 \%$ da variação total explicada para a bacia hidrográfica do rio Piranhas-Assu e $64.2 \%$ para a bacia hidrográfica do rio Paraiba. As interações entre os filtros (fisico/quimico, composição do habitat e paisagem) explicaram melhor a distribuição da abundância das larvas de Chironomidae nas bacias hidrográficas e locais sujeitos a diferentes niveis de distúrbio antropogênico. As condições fisicas e químicas da água e a composição do habitat dependem das características da paisagem, pois as atividades antrópicas desenvolvidas nas bacias hidrográficas aumentam as concentrações de nutrientes na água, promovendo o aumento do estado trófico do ambiente e a homogeneização dos habitats. Este estudo, mostrou que, independente do nivel de disturbio antropogênico, as interações entre os fatores ambientais atuam como fortes filtros ambientais na distribuição das comunidades locais, a exemplo, das assembléias de Chironomidae.

Palavras chave: degradação ambiental, macroinvertebrados bentônicos, seleção de espécies, reservatórios, semi-árido

\section{INTRODUCTION}

Ecologists seek to understand the processes involved in the selection of species that constitute communities (Diamond, 1975; Berryman \& Millstein, 1989; Hubbell, 2001). Studies investigating the factors that could operate on species selection (also known as "assembly rules") initially focused on competitive relationships (Diamond, 1975; Holt, 1977), although later studies suggested that community compositions could reflect species combinations responding to different environmental filters (Keddy, 1992; Poff, 1997). Environmental filters can be classified as phylogeographic (speciation histories, extinctions, and migrations) or ecological (interactions of biotic and abiotic factors) (Keddy, 1992; Vergnon et al., 2009; Götzenberger et al., 2012).

Environmental filters act at different spatial scales to select species capable of becoming established in any given locality (Keddy, 1992; Poff, 1997; Götzenberger et al., 2012). That selection process acts on intrinsic characteristics of the species, so that only species with the best combinations of characteristics for a specific local environmental will become successfully established (Poff, 1997; Heino et al., 2007; Bedoya et al., 2011). In spite of the effects of environmental filters on species selection, dispersal potential allows some species to exist in inadequate habitats even though they cannot establish viable populations (Leibold et al., 2004; Winegardner et al., 2012).

The main filters that select species in aquatic ecosystems are the physical/chemical conditions of the water, habitat characteristics, and biological interactions (Poff, 1997). Anthropogenic disturbances also are considered filters of local species selection (Heino et al., 2013), and when occurring at watersheds scales they can exert severe pressure on aquatic ecosystems and promote changes on small spatial scales (Allan, 2004). Those anthropogenic modifications result in the deterioration of the physical habitat and water quality, affect the natural dynamics of communities, and increase the interactional complexity between the factors that govern local species assemblage compositions (Bruno et al., 2014; Azevêdo et al., 2017). Sites with lower levels of anthropogenic disturbance, on the other hand, tend to present more diversified habitats, better physical/chemical water conditions, and increased abundances of species sensitive to anthropogenic impacts (Molozzi et al., 2013). The effects of disturbances on local assemblages will also depend on disturbance frequencies and intensities, initial ecological conditions, and species' sensitivities (Hawkins et al., 2015).

We selected the Chironomidae family (Insecta: Diptera) for this study due to its high abundance and wide sensitivity range to the environmental qualities of freshwater ecosystems (Serra et al., 2016; 2017a,b), especially reservoirs (e.g., Zhang et al., 2010; Magbanua et al., 2015; Beghelli et al., 2016; Azevêdo et al., 2017). Chironomidae tolerance of wide ecological amplitudes allows them to inhabit sites experiencing different levels of anthropogenic impacts, and where members of other invertebrate groups (such as Ephemeroptera, Plecoptera, and Trichoptera) are rare (Odume \& 
Muller, 2011, Serra et al., 2017a). Our main objective was to evaluate how different levels of anthropogenic disturbances and environmental filters (physical and chemical, habitat composition, and landscape) affect Chironomidae abundance in neotropical semiarid watersheds by: i) classifying sites using anthropogenic impact levels as Least Disturbed sites, Intermediate Disturbed sites, and Severely Disturbed sites; ii) determining which filters (physical/chemical, habitat composition, and landscape) most influence Chironomidae abundance in those three site categories. We tested the hypothesis that the interactions between environmental filters exert a strong influence on the abundance of Chironomidae in sites subjected to different levels of anthropogenic disturbances, due to the interdependence between environmental factors acting on multiple spatial scales.

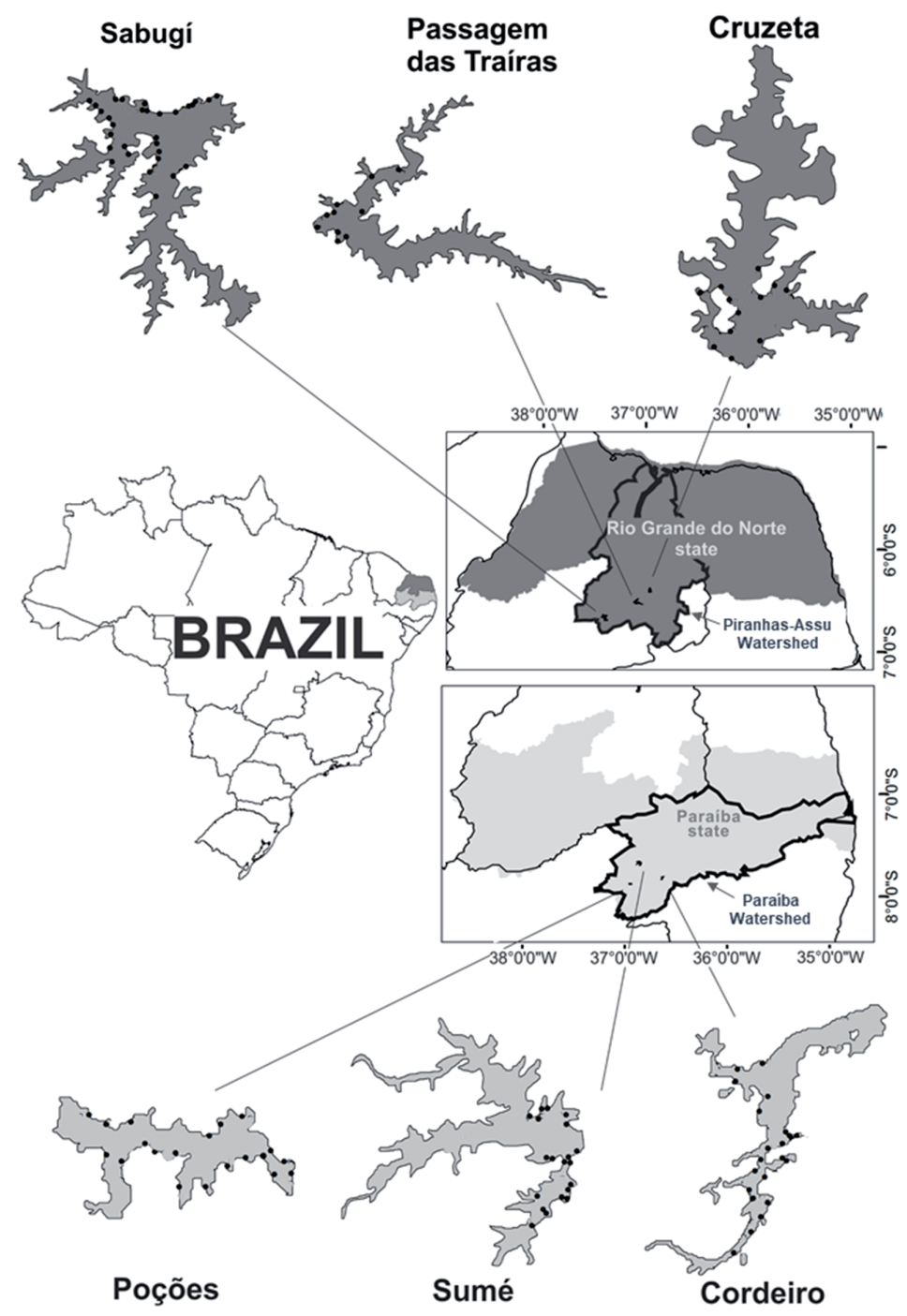

Figure 1. Location of reservoirs and respective sampling sites. Sabugí, Passagem das Traíras, and Cruzeta reservoirs located in the Piranhas-Assu watershed, Rio Grande do Norte and Poções, Sumé, and Cordeiro reservoirs located in the Paraíba watershed, Paraíba, in Northeastern of Brazil. Figure in Jovem-Azevêdo et al. (2019). Localização dos reservatórios e respectivos locais de amostragem. Os reservatórios Sabugí, Passagem das Traíras e Cruzeta, localizados na bacia hidrográfica do rio Piranhas-Assu, Rio Grande do Norte e os reservatórios Poções, Sumé e Cordeiro, localizados na bacia hidrográfica do rio Paraíba, Paraíba, Nordeste do Brasil. Figura em Jovem-Azevêdo et al. (2019). 


\section{MATERIALS AND METHODS}

\section{Study area and sampling sites}

We selected six reservoirs in two watersheds in northeastern Brazil for study: three reservoirs in the Piranhas-Assu watershed in Rio Grande do Norte State, and three in the Paraíba watershed in Paraíba State (Fig. 1). The predominant climate in that region is hot semiarid (BSh, following the Köppen-Geiger classification), with a 9 to 10 month-long dry season, and a mean annual rainfall of approximately $800 \mathrm{~mm}$ in Rio Grande do Norte and $400 \mathrm{~mm}$ in Paraíba (Alvares et al., 2013). Reservoirs located in the Brazilian semiarid region experience anthropic impacts of many types, including from agriculture, ranching, and domestic sewage disposal uses that, together with high reservoir water residence times, contribute to high total nitrogen and total phosphorus levels (Santos \& Eskinazi-Sant'Anna, 2010; Barbosa et al., 2012; Azevêdo et al., 2017).

We sampled 52 sites distributed among the Cruzeta (12 sites), Passagem das Traíras (10), and Sabugí (30) reservoirs in the Piranhas-Assu watershed, as well as 60 sites distributed among the Poções (20 sites), Cordeiro (20), and Sumé (20) reservoirs in the Paraíba watershed (Fig. 1, supplementary material- Table S1 (available at http://www.limnetica.net/en/limnetica)). Those sites were known from previous studies to demonstrate different levels of anthropic disturbances (Gomes et al., 2018). All of the sampling sites were located in the littoral region of the reservoirs (at an average depth of 60 centimeters), because those areas are strongly influenced by the riparian zone and normally harbor the greatest species richness and abundances of benthic macroinvertebrates (Magbanua et al., 2015). The sites were sampled on two occasions, one in June and one in September 2014, during the dry season.

\section{Filter characterizations}

\section{Physical/chemical filters}

The physical/chemical filters considered were based on the parameters of the water sampled at each site. Dissolved oxygen (DO $\mathrm{mg} / \mathrm{L}$ ) and total dissolved solids (TDS $\mathrm{g} / \mathrm{L}$ ) were measured with a multiparameter probe (Horiba U-50); water transparency was determined using a Secchi disk. We sampled a liter of sub-surface water (maximum depth of $0.6 \mathrm{~m}$ ) to determine: total phosphorus concentrations ( $\mathrm{TP} \mu \mathrm{g} / \mathrm{L}$ ), using the ascorbic acid method after digestion with persulfate; reactive soluble phosphate $($ PO4_ $\mu \mathrm{g} / \mathrm{L})$, using the ascorbic acid method; and total nitrogen $(\mathrm{TN} \mu \mathrm{g} / \mathrm{L})$, using the oxidative method. All analyses were performed according to the "Standard Methods for the Examination of Water and Waste Water" (APHA, 2005). We estimated chlorophyll- $a$ concentrations (Chlo- $a \mu \mathrm{g} / \mathrm{L}$ ) by extraction in $90 \%$ acetone, according to the methodology described by Lorenzen (1967).

We based the trophic classification of each site on the Trophic State Index (TSI) proposed by Carlson (1977) and modified by Toledo et al. (1983). That index is calculated based on water transparency $(\mathrm{m})$, total phosphorus concentrations $(\mu \mathrm{g} / \mathrm{L})$, reactive soluble phosphate $(\mu \mathrm{g} / \mathrm{L})$, and chlorophyll- $a$ concentration $(\mu \mathrm{g} / \mathrm{L})$. Values from 0 to 44 correspond to oligotrophic conditions, values from 45 to 54 to mesotrophic conditions, and $>54$ to eutrophic conditions.

\section{Habitat composition filters}

The habitats were characterized according to the granulometric compositions of their sediments. We collected sediment samples at each site using an Eckman-Birge dredge (area 0.225 $\mathrm{m}^{2}$ ) and determined their granulometric compositions following the methodology described by Suguio (1973) and modified by Callisto \& Esteves (1996), as recommended in other studies (e.g., Molozzi et al. (2013), Azevêdo et al. (2017), and Gomes et al. (2018)). We dried the sediment samples at $60{ }^{\circ} \mathrm{C}$ for 72 hours and mechanically separated the fractions by mechanical agitation through a series of sieves. The particles were subsequently classified into six categories: gravel $(>1 \mathrm{~mm})$; coarse sand $(500-1000 \mu \mathrm{m})$; middle sand $(250-500 \mu \mathrm{m})$; fine sand (125 - $250 \mu \mathrm{m})$; silt (63 - $125 \mu \mathrm{m})$; and mud $(<63 \mu \mathrm{m})$. 


\section{Landscape filters}

We used the River Habitat Survey protocol, 2003 version, modified by Rowan et al. (2006) for lentic water bodies to characterize landscape components. We evaluated land use at each sampling site to a distance of $50 \mathrm{~m}$ from the littoral region to the riparian margin, to both the left and the right of the sampling point, noting: urbanization (the presence or absence of human residences) and agricultural areas (the presence or absence of pastures or agricultural areas).

\section{Chironomidae assemblages}

We collected Chironomidae larvae along the littoral region of the reservoirs (at an average depth of 60 centimeters) using an Eckman-Birge dredger (area $0.225 \mathrm{~m}^{2}$ ), subsequently fixing them in situ in $10 \%$ formaldehyde. The samples were washed in the laboratory using $0.50 \mathrm{~mm}$ sieves and the chironomids identified to the genus level based on specialized identification keys (Trivinho-Strixino \& Strixino, 1995; TrivinhoStrixino, 2011).

\section{Data Analysis}

\section{Sampling site classifications}

Before performing the statistical analyses, we analyzed auto-correlations among the environmental variables using the inflation factor (VIF). As no highly correlated values were identified, all of the previously selected variables were maintained. To test for significant differences in environmental characteristics between watersheds, we performed Permutational Multivariate Analysis of Variance (PerMANOVA, 9999 permutations; $\alpha \leq 0.05)$. Significant differences were observed in the environmental characteristics among watersheds (PerMANOVA: Pseudo-F 1.223 $=8.359 ; p=0.001)$.

Principal Components Analysis (PCA, bi-dimensional plot) was used to discriminate the sites in terms of their levels of anthropogenic disturbance based on environmental parameters, following the approach proposed by Molozzi et al. (2013), Azevêdo et al. (2017), and Gomes et al.
(2018) (supplementary material- Table S2, available at http://www.limnetica.net/en/limnetica). Different from what we had predicted, PCA showed the formation of only two groups: sites with the lowest levels of anthropogenic disturbance were considered Least Disturbed sites (LD); sites with the highest levels of anthropogenic disturbance were considered Severely Disturbed sites (SD). Subsequent analyses were performed based on the formation of two groups showing different disturbance levels. We subsequently performed Permutational Multivariate Analysis of Variance (PerMANOVA, 9999 permutations; $\alpha \leq 0.05$ ) to confirm that the differences between these two groups were significant.

\section{Chironomidae assemblages and environmental filters}

To evaluate which environmental filter had the greatest influence on the distribution of Chironomidae larvae (transformed by $\log \mathrm{x}+1$ ), and to explain the independent and shared effects (interactions) of the data set, we used the canonical variance partitioning as proposed by Borcard et al. (1992), and adapted by Cushman \& McGarigal (2002). A series of Canonical Correspondence Analysis (CCA) and Partial Canonical Correspondence Analysis (pCCAs) was used to partition data variance (Cushman \& McGarigal, 2002). Six combinations of environmental matrices were used to obtain the total inertia values and the variance explained, being: $\mathrm{a}=$ physi$\mathrm{cal} /$ chemical; $\mathrm{b}=$ habitat; $\mathrm{c}=$ landscape; $\mathrm{d}=$ physical/chemical + landscape; e = physi$\mathrm{cal} /$ chemical + habitat; $\mathrm{f}=$ habitat + landscape. The percentages of independent and shared explanations were calculated using simple mathematical equations. Those analyses were performed separately for Least Disturbed sites (LD) and Severely Disturbed sites (SD), in each watershed. In a preliminary Detrended Correspondence Analysis (DCA), our biological data exhibited a relatively long gradient (DCA axis 1 $\mathrm{SD}>2$ ), and species responses were primarily unimodal, implying that CCA is suitable for analyzing the data (Heino \& Mykrä, 2008). The statistical significances of those analyses were obtained using Monte Carlo tests with 1000 
permutations of all canonic axes. All of the analyses were conducted using $\mathrm{R}$ software, version 3.2.2 (R Core Development Team, 2017), with the vegan package.

\section{RESULTS}

\section{Sampling site classifications}

The PCA of the Piranhas-Assu watershed showed two groups of sites with different levels of anthropogenic disturbance: $21 \mathrm{LD}$ and $31 \mathrm{SD}$ sites (Fig. 2A). The first and second axes of the
PCA explained $40.02 \%$ and $17.58 \%$ of the data variability, respectively, and were correlated mainly with silt (0.80) and gravel (0.85) (supplementary material- Table S3, available at http:// www.limnetica.net/en/limnetica); the LD and SD groups were significantly different (PerMANOVA: Pseudo-F $1.51=16.157 ; p=0.001)$. The PCA of the Paraíba watershed sites showed two groups with different levels of anthropogenic disturbance: $20 \mathrm{LD}$ sites and $40 \mathrm{SD}$ sites (Fig. 2B). The first and second axes of the PCA explained $35.80 \%$ and $17.85 \%$ of the data variability, respectively, being correlated mainly with
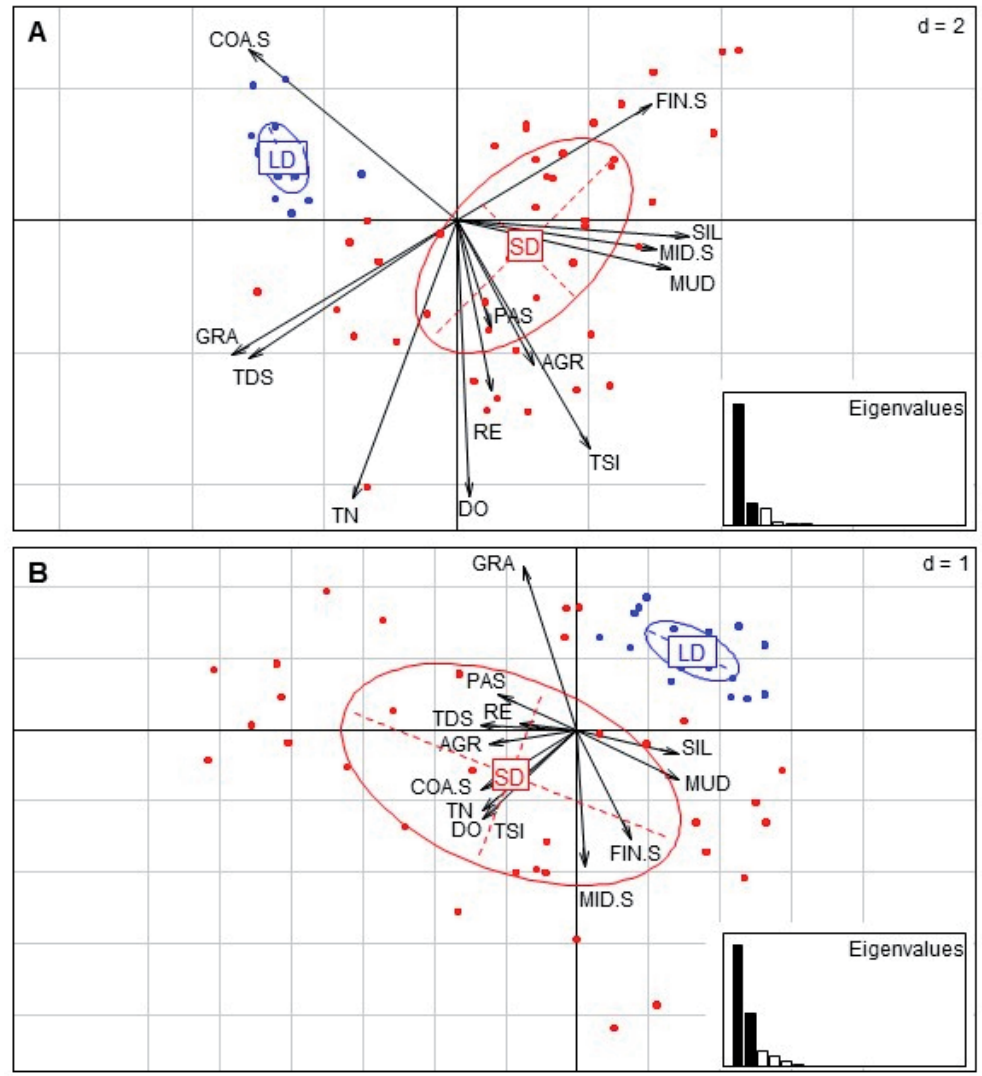

Figure 2. Results of PCA performed on the variables indicative of anthropogenic disturbance collected in the Piranhas-Assu watershed (A) and in Paraíba watershed (B) in Northeastern Brazil. Where: LD = Least Disturbed sites; SD = Severely disturbed sites; OD = Dissolved oxygen; TDS = Total dissolved solids; NT = Total nitrogen; TSI = Trophic State Index; OM = Organic matter; GRA = Gravel; COA.S = Coarse sand; MID.S = Middle sand; FIN.S = Fine sand; SIL = Silt; MU = Mud; RE = Presence of residence; PAS = Pasture area; $\mathrm{AGR}=$ Presence of agriculture. Resultados da ACP realizadas com base nas variáveis indicadoras de impacto antrópico coletadas na bacia hidrográfica do rio Piranhas-Assu (A) e na bacia hidrográfica do rio Paraíba (B) Nordeste do Brasil. Onde: LD = Locais menos perturbados; $S D=$ Locais severamente perturbados; $D O=$ oxigénio dissolvido; $T D S=$ Total de sólidos dissolvidos; $N T=$ nitrogênio total; TSI = indice de estado trófico; OM = matéria orgânica; GRA = cascalho; COA.S = areia grossa; MIDS = areia média; FIN.S = areia fina; $S I L=$ Silte; $M U=$ argila; $R E=$ Presença de residência $;$ PAS = Área de pastagem; $A G R=$ Presença de agricultura . 
silt (0.85) and dissolved oxygen (-0.71) (supplementary material- Table $\mathrm{S} 3$, available at http:// www.limnetica.net/en/limnetica); the LD and SD groups were significantly different (PerMANOVA: Pseudo- $\mathrm{F}_{1.59}=8.214 ; p=0.001$ ).

\section{Chironomidae assemblages and environmen- tal filters}

A total of 11214 Chironomidae larvae were collected, distributed among 22 genera (supplementary material- Table S4, available at http:// www.limnetica.net/en/limnetica). The most abun- dant taxa in the LD and SD sites in the Piranhas-Assu watershed were Goeldichironomus (Fittkau, 1965) (2218 and 1708 individuals respectively) and Tanytarsus (Van der Wulp, 1874) (1306 and 975 individuals respectively). The LD sites in the Paraíba watershed showed a dominance of Coelotanypus (Kieffer, 1913) (200 individuals), while the dominant taxa in the SD sites were Aedokritus (Roback, 1958) (231 individuals) and Polypedilum (Kieffer, 1912) (197 individuals).

Variance partitioning of the Piranhas-Assu watershed showed that Chironomidae abun-
A

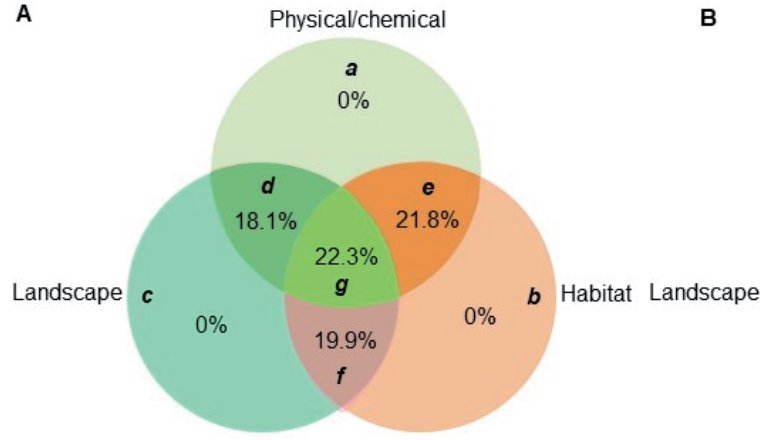

Explained $82.1 \%$

C

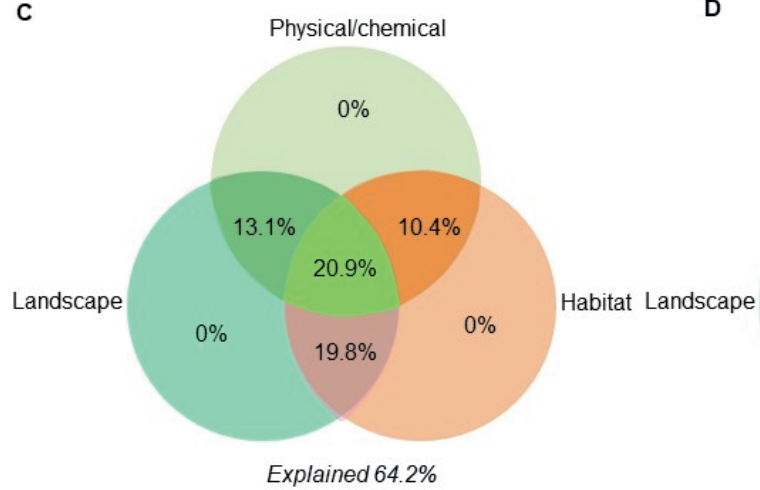

B

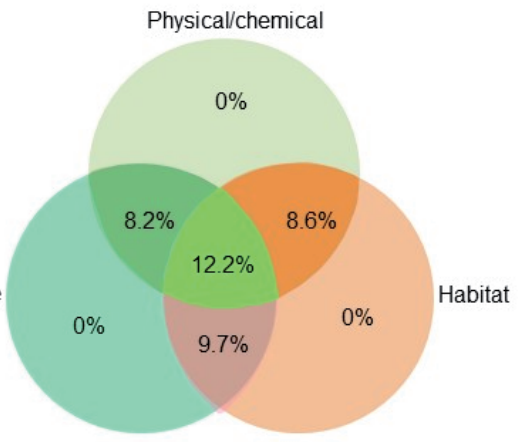

Explained $38.7 \%$

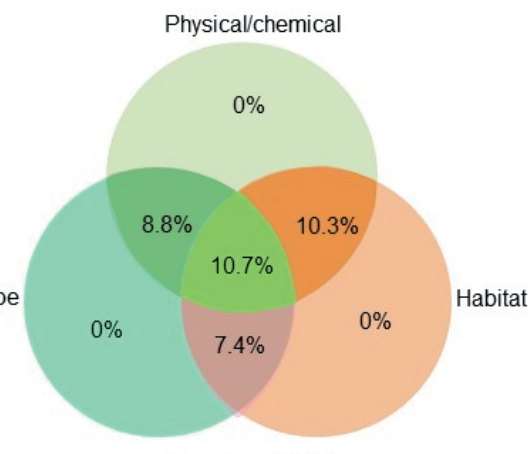

Explained $37.2 \%$

Figure 3. Percentages of independent and shared explanations by environmental filters (physical/chemical, composition of the habitat, and landscape) obtained by a series of CCAs and pCCAs for the selection of Chironomidae larvae. Where: A = Least Disturbed sites in Piranhas-Assu watershed, B = Severely disturbed sites in Piranhas-Assu watershed, C = Least Disturbed sites in Paraiba watershed, and $\mathrm{D}=$ Severely disturbed sites in Paraiba watershed. Results obtained by subtracting of the values of variance explained (Table 1), where: $\mathrm{g}=[\mathrm{f}]+([\mathrm{a}]-[\mathrm{d}])+([\mathrm{a}]-[\mathrm{e}])-[\mathrm{a}] ; \mathrm{d}=[\mathrm{a}]-[\mathrm{e}]-(\mathrm{g}) ; \mathrm{e}=[\mathrm{a}]-[\mathrm{d}]-(\mathrm{g}) ; \mathrm{f}=[\mathrm{b}]-[\mathrm{c}]-(\mathrm{g})$. Porcentagens de explicações independentes e compartilhadas dos filtros ambientais (físicos e químicos, composição do habitat e paisagem) obtidos por uma série de CCAs e pCCAs sobre a seleção de larvas de Chironomidae. Onde: A = Locais menos perturbados na bacia hidrográfica de Piranhas-Assu, $B=$ Locais severamente perturbado na bacia hidrográfica de Piranhas-Assu, C = Locais menos perturbado na bacia hidrográfica do rio Paraíba e D = Locais severamente perturbados na bacia hidrográfica do rio Paraíba. Resultados obtidos pela subtração dos valores de variância explicada (Tabela 1). 
dance explained $82.1 \%$ of the total variance in LD sites and $38.7 \%$ of the total variance in SD sites. Chironomidae abundance in the Paraíba watershed, explained $64.2 \%$ of the total variance in LD sites and $37.2 \%$ in SD sites. Variance partitioning indicated that the interactions of the physical/chemical, habitat composition, and landscape filters (shared roles) best explained Chironomidae abundance distributions in the watersheds (Fig. 3). Those same interactions in the Piranhas-Assu watershed explained $22.3 \%$ of the total variance in LD sites and $12.2 \%$ in SD sites (Fig. 3 A, B), and $20.9 \%$ of the total variance in the Paraíba watershed in LD sites and $10.7 \%$ in SD sites (Fig. 3 C, D).

Table 1. Results of the "Canonical Correspondence Analysis" (CCAs) and (pCCAs) used for the partition of canonical variance of the abundance of Chironomidae in the light of environmental filters (physical/chemical, habitat composition, and landscape), measured at Piranhas-Assu watershed, Rio Grande do Norte and Paraíba watershed, Paraiba Northeastern Brazil. Where: LD= Least Disturbed sites; $\mathrm{SD}=$ Severely disturbed sites. Resultados das "Análises de Correspondência Canônica" (CCAs) e (pCCAs) utilizados para a partição da variância canônica da abundância de Chironomidae à luz de filtros ambientais (físicos e químicos, composição do habitat e paisagem), medidos nas bacias hidrográficas do rio Piranhas-Assu, Rio Grande do Norte e do rio Paraíba, Paraíba, Nordeste do Brasil. Onde: $L D=$ Locais menos perturbados; $S D=$ Locais severamente perturbados.

\begin{tabular}{|c|c|c|c|}
\hline Data set & $\begin{array}{c}\text { Sum of } \\
\text { canonical values }\end{array}$ & $\begin{array}{l}\text { Variance } \\
\text { explained }\end{array}$ & $P($ perm $)$ \\
\hline \multicolumn{4}{|l|}{ LD-Piranhas-Assu watershed } \\
\hline \multicolumn{4}{|c|}{ Abundance of Chironomidae, total inertia $=0.99$} \\
\hline Physical/chemical & 0.2858 & 28.74 & 0.0019 \\
\hline Habitat & 0.0878 & 8.83 & 0.0899 \\
\hline Landscape & 0.0643 & 6.47 & 0.0019 \\
\hline Physical/chemical + landscape & 0.2627 & 28.24 & \\
\hline Physical/chemical + habitat & 0.2572 & 32.90 & \\
\hline Habitat + landscape & 0.078 & 10.06 & \\
\hline \multicolumn{4}{|l|}{ SD-Piranhas-Assu watershed } \\
\hline \multicolumn{4}{|c|}{ Abundance of Chironomidae, total inertia $=0.76$} \\
\hline Physical/chemical & 0.1296 & 16.86 & 0.0009 \\
\hline Habitat & 0.0637 & 8.31 & 0.0049 \\
\hline Landscape & 0.0448 & 5.85 & 0.0009 \\
\hline Physical/chemical + landscape & 0.1183 & 17.21 & \\
\hline Physical/chemical + habitat & 0.1213 & 20.84 & \\
\hline Habitat + landscape & 0.0521 & 8.95 & \\
\hline \multicolumn{4}{|c|}{ LD-Paraiba watershed } \\
\hline \multicolumn{4}{|c|}{ Abundance of Chironomidae, total inertia $=1.80$} \\
\hline Physical/chemical & 0.5414 & 30.01 & 0.0009 \\
\hline Habitat & 0.3663 & 20.31 & 0.0178 \\
\hline Landscape & 0.3456 & 19.15 & 0.0679 \\
\hline Physical/chemical + landscape & 0.5184 & 40.52 & \\
\hline Physical/chemical + habitat & 0.4138 & 37.87 & \\
\hline Habitat + landscape & 0.2995 & 27.41 & \\
\hline \multicolumn{4}{|l|}{ SD-Paraiba watershed } \\
\hline \multicolumn{4}{|c|}{ Abundance of Chironomidae, total inertia $=3.07$} \\
\hline Physical/chemical & 0.4194 & 13.63 & 0.0009 \\
\hline Habitat & 0.2127 & 6.91 & 0.0019 \\
\hline Landscape & 0.1123 & 3.65 & 0.0009 \\
\hline Physical/chemical + landscape & 0.3996 & 14.01 & \\
\hline Physical/chemical + habitat & 0.4001 & 15.48 & \\
\hline Habitat + landscape & 0.1335 & 5.16 & \\
\hline
\end{tabular}




\section{DISCUSSION}

Our results showed that Chironomidae assemblage distributions in watersheds are mainly affected by the interactions of filters physical/chemical, habitat composition, and landscape, confirming our hypothesis. Anthropogenic activities in watersheds (e.g., agriculture, urbanization) frequently increase nutrient concentrations in their waters, which increase the trophic state of the environments and promote habitat homogenization (Allan, 2004; Karaouzas \& Płóciennik, 2015; Azevêdo et al., 2017). The effects of larger-scale anthropogenic activities interact with local factors and influence the compositions and distributions of local communities (Pavlin et al., 2011; Karaouzas \& Płóciennik, 2015).

Although the least disturbed and severely disturbed sites exhibited different environmental characteristics, the filters that exerted the greatest influence on the selection of Chironomidae larvae did not vary between them, differing only in terms of the percentages of variation explained. This can be due to the fact that recently modified habitats tend to be occupied by species that evolved under similar environmental conditions and that show wide ecological plasticity (Heino et al., 2013). The most representative organisms in in the assemblages studied here were generalists - organisms that can be found under varied environmental conditions, have high reproductive rates in numerous habitats, and therefore exhibit wide distributions and dense populations (Odume \& Muller, 2011; Gates et al., 2015; Karaouzas \& Płóciennik, 2015).

In addition to the generalist behaviors of some chironomids (e.g., Goldichironomus, Tanytarsus, and Coelotanypus), the high dispersal capacity of the group could also have influenced our results, as many chironomids are active dispersers and ours sites nearby (Heino \& Mykrä, 2008; Horsák et al., 2015). Our results can be viewed from a metacommunity perspective, especially the "species sorting" or "mass effect" models, where islands with different environmental characteristics are connected through species' dispersals (Leibold et al., 2004; Winegardner et al., 2012). Although high dispersal capacities can allow species to occur in inadequate habitats, that mechanism does not allow the establishment of large populations under adverse environmental conditions due to selection by environmental filters (Braga et al., 2017).

The highest percentages of total variance explained by filters acting on the Chironomidae assemblages were observed in the least disturbed sites because those populations are exposed to a series of, fluctuating but predictable and more stable conditions (Scheffer \& Carpenter, 2003) as compared to severely disturbed sites. Severely disturbed sites, on the other hand, are often subjected to a spectrum of fluctuating disturbances (Feio et al., 2014; Gomes et al., 2018) that cause abrupt environmental changes and complex nonlinear population responses that make their identification and interpretation more difficult (Berryman \& Millstein, 1989; Andersen et al., 2009).

Although the interactions between environmental filters showed high percentages of explanation, other mechanisms, such as biotic interactions, may also play important roles in the abundance and composition of Chironomidae assemblages. Numerous studies have shown that biotic interactions can be extremely important factors in structuring local assemblies, and that those interactions can be intensified under degraded conditions due to increased competition (Conell et al., 2004; Chase et al., 2009; Boersma et al., 2014).

This study showed that, independent of the anthropogenic disturbance level, interactions of environmental factors act as strong environmental filters on the distributions of local communities, such as Chironomidae assemblages. We therefore emphasize the importance of evaluating the independent and shared effects of data sets in light of the complexity of environmental factors that simultaneously affect the aquatic biota. Future studies that consider different seasonal periods may confirm that the patterns observed here during the dry season also occur during the rainy season.

\section{ACKNOWLEDGEMENTS}

The first author thanks the Coordenação de Aperfeiçoamento de Pessoal de Nível SuperiorCAPES for the masters degree scholarship, and 
the Fundação de Apoio a Pesquisa do Estado da Paraíba- FAPESQ. This work was part of the Universal Project CNPq/MCTI (process 446721/ 2014) as well as research productivity scholarships (process 302393/2017-0) of JM. The fourth author was supported by a strategic project (UID/ MAR/04292/2013) granted to MARE. FTM was supported by the Universidad de la República and by the Sistema Nacional de Investigadores (SNI) of Uruguay.

\section{REFERENCES}

AESA, 2015. Agência Executiva de Gestão das Águas do Estado da Paraíba. Available Internet http://www.aesa.pb.gov.br.

ALLAN, J. D. 2004. Landscapes and riverscapes: the influence of land use on stream ecosystems. Annual Review of Ecology, Evolution, and Systematics, 35: 257-284. DOI: 10.1146/ annurev.ecolsys.35.120202.110122

ALVARES, C. A., J. L. STAPE, P. C. SENTELHAS, G. DE MORAES, J. LEONARDO, \& G. SPAROVEK. 2013. Köppen's climate classification map for Brazil. Meteorologische Zeitschrift, 22: 711-728. DOI: 10.1127/ 0941-2948/2013/0507

ANDERSEN, T., J. CARSTENSEN, E. HERNANDEZ-GARCIA \& C. M. DUARTE. 2009. Ecological thresholds and regime shifts: approaches to identification. Trends in Ecology \& Evolution, 24: 49-57. DOI: 10.1016/j.tree. 2008.07.014

APHA, F. 2005. Water Environmental et al. Standard methods for the examination of water and wastewater. American Public Health Association: Washington, DC, USA.

AZEVÊDO, E. L., J. E. L. BARBOSA, L. G. VIANA, M. J. P. ANACLETO, M. CALLISTO \& J. MOLOZZI. 2017. Application of a statistical model for the assessment of environmental quality in neotropical semi-arid reservoirs. Environmental monitoring and assessment, 189: 64-77. DOI: 10.1007/s10661016-5723-3

BARBOSA, J. E. D. L., E. S. F. MEDEIROS, J. BRASIL, R. D. S. CORDEIRO, M. C. B. CRISPIM \& G. H. G. D. SILVA. 2012. Aquatic systems in semi-arid Brazil: limnolo- gy and management. Acta Limnologica Brasiliensia, 24(1): 103-118. DOI: 10.1590/ S2179-975X2012005000030

BEDOYA, D., E. S. MANOLAKOS \& V. NOVOTNY. 2011. Characterization of biological responses under different environmental conditions: a hierarchical modeling approach. Ecological modeling, 222: 532-545. DOI: $10.1016 /$ j.ecolmodel.2010.10.007

BEGHELLI, F. G. S., M. POMPÊO, A. H. ROSA \& V. M. CARLOS. 2016. Effects of copper in sediments on benthic macroinvertebrate communities in tropical reservoirs. Limnetica, 35: 103-116. DOI: 10.23818/limn.35.09

BERRYMAN, A. A. \& J. A. MILLSTEIN. 1989. Are ecological systems chaotic and if not, why not? Trends in Ecology \& Evolution, 4: 26-28. DOI: 10.1016/0169-5347(89)90014-1

BOERSMA, K. S., M. T. BOGAN, B. A. HENRICHS \& D. A. LYTLE. 2014. Invertebrate assemblages of pools in arid-land streams have high functional redundancy and are resistant to severe drying. Freshwater Biology, 59(3): 491-501. DOI: 10.1111/fwb.12280

BORCARD, D., P. LEGENDRE \& P. DRAPEAU. 1992. Partialling out the spatial component of ecological variation. Ecology, 73: 1045-1055. DOI: $10.2307 / 1940179$

BRAGA, C., J. A. DE OLIVEIRA \& R. CERQUEIRA. 2017. Metacomunidades: uma introdução aos termos e conceitos. Oecologia Australis, 21: 108-118. DOI: 10.4257/oeco.2017 .2102 .02

BRUNO, D., O. BELMAR, D. SÁNCHEZFERNÁNDEZ, S. GUARESCHI, A. MILLÁN \& J. VELASCO. 2014. Responses of Mediterranean aquatic and riparian communities to human pressures at different spatial scales. Ecological Indicators, 45: 456-464. DOI: 10.1016/j.ecolind.2014.04.051

CALLiSTO, M. \& F. A. ESTEVES. 1996. Composição granulométrica do sedimento de um lago amazônico impactado por rejeito de bauxita e um lago natural (Pará, Brasil). Acta Limnologica Brasiliensia, 8: 115-126.

CARLSON, R. E. 1977. A trophic state index for lakes. Limnology and Oceanography, 22: 361-369. DOI: 10.4319/1o.1977.22.2.0361

CHASE, J. M., E. G. BIRO, W. A. RYBERG \& 
K. G. SMITH. 2009. Predators temper the relative importance of stochastic processes in the assembly of prey metacommunities. Ecology letters, 12(11): 1210-1218. DOI: 10.1111/ $.1461-0248.2009 .01362 . \mathrm{x}$

CONNELL, J. H., T. P. HUGHES, C. C. WALLACE, J. E. TANNER, K. E. HARMS \& A. M. KERR. 2004. A long-term study of competition and diversity of corals. Ecological Monographs, 74(2): 179-210. DOI: 10.1890/02-4043

CUSHMAN, S. A. \& K. MCGARIGAL. 2002. Hierarchical, multi-scale decomposition of species-environment relationships. Landscape Ecology, 17: 637-646. DOI: 10.1023/ A:1021571603605

DIAMOND, J. M. 1975. 'Assembly of species communities. Ecology and evolution of communities'. (Harvard University Press: Cambridge).

FEIO, M. J., F. C. AGUIAR, S. F. P. ALMEIDA, J. FERREIRA, M. T. FERREIRA, C. ELIAS, ... \& C. VIEIRA. 2014. Least disturbed condition for European Mediterranean rivers. Science of the Total Environment, 476: 745-756. DOI: 10.1016/j.scitotenv.2013. 05.056

GATES, K. K., C. C. VAUGHN \& J. P. JULIAN. 2015. Developing environmental flow recommendations for freshwater mussels using the biological traits of species guilds. Freshwater Biology, 60: 620-635. DOI: 10.1111/fwb. 12528

GOMES, W. I. A., D. DA SILVA JOVEM-AZEVÊDO, F. F. PAIVA, S. V. MILESI \& J. MOLOZZI. 2018. Functional attributes of Chironomidae for detecting anthropogenic impacts on reservoirs: A biomonitoring approach. Ecological Indicators, 93: 404-410. DOI: 10.1016/j.ecolind. 2018.05.006

GÖTZENBERGER, L., F. DE BELLO, K. A. BRÅTHEN, J. DAVISON, A. DUBUIS, A. GUISAN，J. LEPS， R. LINDBORG，R. MOORA, M. PARTEL, L. PELLISSIER, J. POTTIER, P. VITTOZ, K. ZOBEL \& M. ZOBEL. 2012. Ecological assembly rules in plant communities- approaches, patterns and prospects. Biological reviews, 87: 111-127. DOI: $10.1111 /$ j.1469-185X.2011.00187.x
HAWKINS, C. P., H. MYKRÄ, J. OKSANEN \& J. J. VANDER LAAN. 2015. Environmental disturbance can increase beta diversity of stream macroinvertebrate assemblages. Global Ecology and Biogeography, 24: 483-494. DOI: 10.1111/geb.12254

HEINO, J., H. MYKRÄ, J. KOTANEN \& T. MUOTKA. 2007. Ecological filters and variability in stream macroinvertebrate communities: do taxonomic and functional structure follow the same path? Ecography, 30: 217-230. DOI: 10.1111/j.0906-7590.2007.04894.x

HEINO, J. \& H. MYKRÄ. 2008. Control of stream insect assemblages: roles of spatial configuration and local environmental factors. Ecological Entomology, 33: 614-622. DOI: 10.1111/j.1365-2311.2008.01012.x

HEINO, J., D. SCHMERA \& T. ERÖS. 2013. A macroecological perspective of trait patterns in stream communities. Freshwater Biology, 58: 1539-1555. DOI: 10.1111/fwb.12164

HOLT, R. D. 1977. Predation, apparent competition, and the structure of prey communities. Theoretical population biology, 12: 197-229. DOI: 10.1016/0040-5809(77)90042-9

HORSÁK, M., V. RÁDKOVÁ, V. SYROVÁTKA, J. BOJKOVÁ, V. KŘOUPALOVÁ, J. SCHENKOVÁ \& J. ZAJACOVÁ. 2015. Drivers of aquatic macroinvertebrate richness in spring fens in relation to habitat specialization and dispersal mode. Journal of biogeography, 42: 2112-2121. DOI: 10.1111/jbi.12569

HUBBELL, S. P. 2001. 'The unified neutral theory of biodiversity and biogeography (MPB-32)'. (Princeton University Press).

JOVEM-AZEVÊDO, D., J. F. BEZERRA-NETO, E. L. AZEVÊDO, W. I. A. GOMES, J. MOLOZZI \& M. J. FEIO. 2019. Dipteran assemblages as functional indicators of extreme droughts. Journal of arid environmments, 164: 12-22. DOI: 10.1016/j. jaridenv.2019.01.014

KARAOUZAS, I. \& M. PŁÓCIENNIK. 2015. Spatial scale effects on Chironomidae diversity and distribution in a Mediterranean River Basin. Hydrobiologia, 767: 81-93. DOI: 10.1007/s10750-015-2479-7

KEDDY, P. A. 1992. Assembly and response rules: two goals for predictive community 
ecology. Journal of Vegetation Science, 3: 157-164. DOI: $10.2307 / 3235676$

LEIBOLD, M. A., M. HOLYOAK, N. MOUQUET, P. AMARASEKARE, J. M. CHASE, M. F. HOOPES, ... \& M. LOREAU. 2004. The metacommunity concept: a framework for multi-scale community ecology. Ecology letters, 7: 601-613. DOI: 10.1111/j.1461-0248. 2004.00608.x

LORENZEN, C. J. 1966. A method for the continuous measurement of in vivo chlorophyll concentration. Deep Sea Researchs, 13: 223-227. DOI: 10.1016/0011-7471(66) 91102-8

MAGBANUA, F. S., N. Y. B. MENDOZA, C. J. C. UY, C. D. MATTHAEI \& P. S. ONG. 2015. Water physicochemistry and benthic macroinvertebrate communities in a tropical reservoir: The role of water level fluctuations and water depth. Limnologica-Ecology and Management of Inland Waters, 55: 13-20. DOI: 10.1016/j.limno.2015.10.002

MOLOZZI, J., M. J. FEIO, F. SALAS, J. C. MARQUES \& M. CALLISTO. 2013. Maximum ecological potential of tropical reservoirs and benthic invertebrate communities. Environmental Monitoring and Assessmenta 1, 185: 6591-6606. DOI: 10.1007/s10661-012-3049-3

ODUME, O. N. \& W. J. MULLER. 2011. Diversity and structure of Chironomidae communities in relation to water quality differences in the Swartkops River. Physics and Chemistry of the Earth, 36: 929-938. DOI: 10.1016/j.pce. 2011.07.063

PAVLIN, M., S. BIRK, D. HERING \& G. URBANIC. 2011. The role of land use, nutrients, and other stressors in shaping benthic invertebrate assemblages in Slovenian rivers. Hydrobiologia, 678: 137-153. DOI: 10.1007/ s10750-011-0836-8

POFF, N. L. 1997. Landscape filters and species traits: towards mechanistic understanding and prediction in stream ecology. Journal of the North American Benthological Society, 16: 391-409. DOI: $10.2307 / 1468026$

ROWAN, J. S., J. CARWARDINE, R. W. DUCK, O. M. BRAGG, A. R. BLACK, M. E. J. CUTLER \& P. J. BOON. 2006. Development of a technique for lake habitat survey (LHS) with applications for the European Union Water Framework Directive. Aquatic Conservation: Marine and Freshwater Ecosystems, 16: 637-657. DOI: 10.1002/aqc.786

R Development Core Team. 2017. R: Language and environment for statistical computing foundation for Statistical Computing. Version 3.2 .2

SANTOS, C. M. \& E. M. ESKINAZI-SANT'ANNA. 2010. The introduced snail Melanoides tuberculatus (Muller, 1774) (Mollusca: Thiaridae) in aquatic ecosystems of the Brazilian semiarid northeast (Piranhas-Assu River basin, State of Rio Grande do Norte). Brazilian Journal of Biology, 70(1): 1-7. DOI: 10.1590/S1519-69842010000100003

SCHEFFER, M. \& S. R. CARPENTER. 2003. Catastrophic regime shifts in ecosystems: linking theory to observation. Trends in ecology \& evolution, 18: 648-656. DOI: 10.1016/j. tree.2003.09.002

SEMARH, 2015. Secretaria do Meio Ambiente e dos Recursos Hídricos do Estado do Rio Grande do Norte. Available Internet http:// www.semarh.rn.gov.br.

SERRA, S. R., F. COBO, M. A. GRACA, S. DOLEDEC \& M. J. FEIO. 2016. Synthesising the trait information of European Chironomidae (Insecta: Diptera): Towards a new database. Ecological indicators, 61: 282-292. DOI: 10.1016/j.ecolind.2015.09.028

SERRA, S. R. Q., M. S. A. GRAÇA, S. DOLÉDC \& M. J. FEIO. 2017a Chironomidae traits and life history strategies as indicators of anthropogenic disturbance. Environmental Monitoring and Assessment, 189: 326. DOI: $10.1007 / \mathrm{s} 10661-017-6027-y$

SERRA, S. R. Q., M. A. GRAÇA, S. DOLÉDEC \& M. J. FEIO. 2017b Discriminating permanent from temporary rivers with traits of chironomid genera. Annales de Limnologie-International Journal of Limnology, 53: 161-174. DOI: 10.1051/limn/2017004

SUGUIO, K. 1973. 'Introdução à sedimentologia'. (Edgard Blucher: São Paulo.)

TOLEDO, A., M. TALARICO, S. J. CHINEZ \& E. G. AGUDO. 1983. A aplicação de modelos simplificados para a avaliação do processo de eutrofização em lagos e reservatórios tropic- 
ais. In 'Anais do $12^{\circ}$ Congresso Brasileiro de Engenharia Sanitária e Ambiental'. Camboriú. p. 1-34.

TRIVINHO-STRIXINO, S. \& G. STRIXINO. 1995. Larvas de Chironomidae (Diptera) do Estado de São Paulo: Guia de identificação e diagnose dos gêneros.

TRIVINHO-STRIXINO, S. 2011. Chironomidae (Insecta Diptera, Nematocera) do Estado de São Paulo, Sudeste do Brasil. Biota Neotropica, 11: 1-10. DOI: 10.1590/S167606032011000500032

VERGNON, R., N. K. DULVY \& R. P. FRECKLETON. 2009. Niches versus neutrality: uncovering the drivers of diversity in a species-rich community. Ecology letters, 12: 1079-1090. DOI: 10.1111/j.1461-0248.2009. 01364.x

WINEGARDNER, A. K., B. K. JONES, I. S. NG, T. SIQUEIRA \& K. COTTENIE. 2012. The terminology of metacommunity ecology. Trends in ecology \& evolution, 27: 253-254. DOI: 10.1016/j.tree.2012.01.007

ZHANG, M., M. SHAO, Y. XU \& Q. CAI. 2010. Effect of hydrological regime on the macroinvertebrate community in Three-Gorges Reservoir, China. Quaternary International, 226: 129-135. DOI: 10.1016/j.quaint.2009.12.019 